\title{
Lead isotopic mapping of galena from the southern Korean Peninsula
}

\author{
Youn-JoOng JEONG *, AlBERT CHANG-SIK CHEONG
}

Korea Basic Science Institute, Chungcheongbukdo 28119, Republic of Korea (*correspondence: hero0123@kbsi.re.kr)

Lead isotopes have been widely used for tracing the provenance of soils, dusts, minerals, and archaeological relics. This study presents a comprehensive lead isotopic database of galena collected from base metal deposits in the southern Korean Peninsula, which is geotectonically subdivided into the Gyeonggi Massif, the Okcheon Belt (including the Taebaeksan Basin), the Yeongnam Massif, and the Gyeongsang Basin from north to south. Four isotopic zones were identified by the linear discriminant analysis. Galena samples from zone 1, geotectonically corresponding to the Gyeongsang Basin, are fairly homogeneous in lead isotopic composition $\left({ }^{206} \mathrm{~Pb} /{ }^{204} \mathrm{~Pb}=18.156-18.591,{ }^{207} \mathrm{~Pb} / 204 \mathrm{~Pb}=\right.$ $\left.15.482-15.644,{ }^{208} \mathrm{~Pb} /{ }^{204} \mathrm{~Pb}=37.870-38.768\right)$. Galena lead isotopic composition of zone 2, corresponding to the Taebaeksan Basin and the northeastern Yeongnam Massif, is the most radiogenic $\left({ }^{206} \mathrm{~Pb} / 204 \mathrm{~Pb}=18.625-20.483\right.$, $\left.{ }^{207} \mathrm{~Pb} /{ }^{204} \mathrm{~Pb}=15.708-16.068,{ }^{208} \mathrm{~Pb} /{ }^{204} \mathrm{~Pb}=37.734-40.463\right)$. Galena samples from the western Gyeonggi Massif, grouped as zone 4 , show relatively unradiogenic ratios $\left({ }^{206} \mathrm{~Pb} / 204 \mathrm{~Pb}=\right.$ $17.149-17.817,{ }^{207} \mathrm{~Pb} /{ }^{204} \mathrm{~Pb}=15.497-15.731,{ }^{208} \mathrm{~Pb} / 204 \mathrm{~Pb}=$ 37.847-39.773). The remaining areas, including the Okcheon metamorphic belt, central-eastern Gyeonggi Massif, and the Yeongnam Massif, are grouped as zone 3. This map provides a fundamental basis for constructing a lead isoscape of the Korean Peninsula for human provenance. 